\title{
ІНШІ ЗАХОДИ КРИМІНАЛЬНО-ПРАВОВОГО ХАРАКТЕРУ ЗА КРИМІНАЛЬНІ ПРАВОПОРУШЕННЯ, ЩО ПОСЯГАЮТЬ НА ГРОМАДСЬКУ ТА ПРИВАТНУ ПРОФЕСІЙНУ ОХОРОННУ ДІЯЛЬНІСТЬ
}

\begin{abstract}
СИЙПЛОКІ Микола Васильович - кандидат юридичних наук, доцент, доцент кафедри кримінального права і процесу Ужгородського національного університету
\end{abstract}

DOI:10.32782/EP.2020.1.11

УДК 343.22(477)

Встановлено, що передумовами до появи в украӥнському законодавстві інституту інших заходів кримінально-правового характеру (Розділ XIV) та заходів кримінально-правового характеру щзодо юридичних осіб Розділ (XIV1) є політико - правові реббормаціӥ, пов'язані iз наближенням законодавства Украӥни до європейсъких стандартів.

Визначено, що науково - практичні підходи щодо основних ознак інших заходів кримінально - правового характеру неоднозначні, а іноді суперечливі, є суттеві розбіжності в понятійному апараті, а тому актуальним вбачається широкий науковий пошук у напрямках з'ясування проблемних питань 3 метою успішного впровадження нововведень у правозастосовну діяльність.

Розглянуто основні доктринальні підходи щодо бормулювання поняття $і$ визначення видів інших заходів кримінально-правового характеру. Визначено ті злочини у сфері охоронної діяльності за виинення яких можуть бути застосовані інші заходи кримінальноправового характеру.

Проаналізовано окремі інші заходи кримінально-правового характеру за кримінальні правопорушення, що посягають на громадсъку приватну пробесійну охоронну діяльнiсmь.

Зроблено висновок про дочільність доповнення переліку підстав застосування до юридичних осіб заходів кримінально-правового характеру за рахунок включення до нъого кримінальних правопорушень у сфері гро-

= Свропейські перспективи № $1,2020=68$ мадської та приватної пробесійної охоронної діяльності, передбачених ст. 194, 206, 352, 355, 359, 368, 368-2 КК України.

Ключові слова: заходи кримінально-правового характеру, покарання, охоронна діяльність, приватна охоронна діяльність, кримінальна відповідальність, злочини у сфері охоронної діяльності.

\section{Постановка проблеми}

Активні державні перетворення, що відбуваються останніми роками в Україні, зумовлюють необхідність удосконалення механізму правового регулювання відповідних процесів. Уже сьогодні більшість розвинених держав світу, поступово відступаючи від постулатів неокласичної школи кримінального права і виходячи із мети ресоціалізації винного, як основної мети кримінального закону, у своїй кримінально-правовій політиці дотримується дуалізму покарань та інших заходів кримінально-правового впливу. Насамперед, так званих «заходів безпеки» (у різних кримінальних кодексах останні іменуються також як «кримінально-правові заходи», «заходи виправлення і безпеки», «заходи впливу», «інші заходи кримінальноправового характеру», «особливі правові наслідки злочину», «інші правові наслідки злочину» тощо) [1, с. 6-7].

На вимогу часу та у відповідності до цілого ряду ратифікованих Україною міжнародно-правових документів у національному законодавстві було запроваджено 
інститут інших заходів кримінально-правового характеру (Розділ XIV) та заходів кримінально-правового характеру щодо юридичних осіб (Розділ XIV-1).

Слід відмітити, що наукові підходи до визначення загального поняття цих заходів, їх системи, змісту, підстав та порядку застосування, співвідношення 3 іншими суміжними кримінально-правовими поняттями - неоднозначні, а іноді суперечливі, а тому потребують активізації науково-практичних досліджень 3 метою успішного подальшого впровадження у правозастосовну діяльність. У цьому зв'язку особливо актуальним вважається зосередження наукової уваги на інших заходах кримінально-правового характеру за кримінальні правопорушення, що посягають на громадську та приватну професійну охоронну діяльність.

\section{Аналіз останніх досліджень і публікацій}

Проблемі застосування в Україні заходів кримінально-правового характеру присвячено наукові праці таких учених як П. П. Андрушка, В. С. Батраченка,T. О. Гончара, В. К. Грищука, Н. О. Гуторової, А. С. Нерсесяна, Н. А. Орловської, М. I. Панова, О. Ф. Пасєки, П. А. Фріса, М. І. Хавронюка, С. О. Харитонова, Г. З. Яремко, А. М. Ященка та інших. Однак їх дослідження торкалися переважно загальної характеристики інших заходів кримінально-правового характеру без посилання на кримінальні правопорушення, що посягають на громадську та приватну професійну охоронну діяльність, у зв’язку з чим метою даної публікації є дослідження доктринальних поглядів щодо розуміння поняття та змісту «інших заходів кримінально-правового характеру» та характеристики інших заходів кримінально-правового характеру, що застосовуються в означеній вище специфічній сфері діяльності.

\section{Виклад основного матеріалу}

Поряд із покаранням за вчинення кримінальних правопорушень, що посягають на громадську та приватну професійну охо- ронну діяльність, до винних осіб за кримінальним законодавством України можуть бути застосовані інші заходи кримінально-правового характеру. Зауважимо, що у юридичній літературі не існує єдності думок у питанні розуміння цих засобів кримінально-правового впливу. Так, окремі науковці, спираючись на приписи чинного КК України, стверджують, що до інших заходів кримінально-правового характеру належать ті заходи, що закріплені у розділі XIV і XIV-1 Загальної частини КК України, а саме: примусові заходи медичного характеру (ст. ст. 92-95), примусове лікування (ст. 96), спеціальна конфіскація (ст. ст. 96-1, 96-2), заходи кримінально-правового характеру щодо юридичних осіб - штраф, конфіскація майна, ліквідація (ст. ст. 963-96-11) [2, с. 467]. Інші більш ширше розуміють такі засоби впливу.

Наукові позиції з цього приводу різні, однак ми доходимо до висновку, що інші заходи кримінально-правового характеру не обмежуються лише тими засобами впливу на порушників кримінально-правових заборон, що містяться у розділі XIV Загальної частини КК України «Інші заходи кримінально-правового характеру».

У зв'язку з цим, зазначимо, що серед низки таких заходів до порушників кримінально-правових заборон у сфері громадської та приватної професійної охоронної діяльності в Україні поряд, насамперед, 3 покаранням може бути застосований такий інший захід кримінально-правового характеру, як спеціальна конфіскація.

Спеціальну конфіскацію, як один із заходів кримінально-правового характеру, у 2017 р. застосовано до 400 засуджених осіб (за вироками, що набрали і не набрали законної сили) [3].

Згідно з ч. 1 ст. 96-1 КК України спеціальна конфіскація полягає у примусовому безоплатному вилученні за рішенням суду у власність держави грошей, цінностей та іншого майна у випадках, визначених КК, за умови вчинення умисного кримінального правопорушення або суспільно небезпечного діяння, що підпадає під ознаки діяння, передбаченого Особливою частиною КК, за які передбачено основне пока- 


\section{Кримінальне право, кримінальний процес та криміналістика}

рання у виді позбавлення волі або штрафу понад три тисячі неоподатковуваних мінімумів доходів громадян, а так само передбаченого частиною першою статті 150 , статтею 154 частинами другою і третьою статті 159-1, частиною першою статті 190 , статтею 192, частиною першою статей 204, 209-1, 210, частинами першою і другою статей 212, 212-1, частиною першою статей 222, 229, 239-1, 239-2, частиною другою статті 244, частиною першою статей 248, 249, частинами першою і другою статті 300, частиною першою статей 301 , 302, 310, 311, 313, 318, 319, 362,статтею 363, частиною першою статей 363-1, 364-1, 365-2 КК України.

За справедливим зауваженням окремих дослідників спеціальна конфіскація не ставить перед собою цілей виправлення особи або попередження нових кримінальних правопорушень. Единою метою iii застосування $\epsilon$ недопустимість використання предметів, що підлягають вилученню, в нових кримінальних правопорушеннях, та залишення в користуванні злочинця предметів, здобутих злочинним шляхом [4, с.31].

Таким чином, з огляду на вказані законодавчі норми спеціальна конфіскація може бути застосована до майна засудженого чи у передбачених КК випадках - до майна іншої особи, яке використовувалося як знаряддя вчинення злочину, передбаченого ч. 1 ст. 267-1 КК. Верховний Суд не виключає в цілому можливості застосування спеціальної конфіскації навіть у тих випадках, коли конфіскація майна, з огляду на його вартість, виглядає набагато суворішим заходом, ніж призначене покарання. Однак у таких випадках суд має навести належні аргументи, які обгрунтовують, 3 урахуванням обставин конкретної справи, що такий захід не порушуватиме наведені вище стандарти ЄСП $\mathcal{~}$. При цьому до уваги можуть братися: вартість майна, що підлягає конфіскації, законність чи незаконність його походження; тяжкість і характер вчиненого злочину; наявність, розмір і характер завданої шкоди або шкоди, яка потенційно могла бути завдана злочи-

\section{Європейські перспективи № 1, $2020=$}

ном; вид і розмір призначеного покарання тощо [5].

Спеціальна конфіскація, як інший захід кримінально-правового характеру, у випадках, передбачених ст. 96-2 КК України, може бути застосована до особи у випадку вчинення кримінальних правопорушень (злочинів i кримінальних проступків) у сфері громадської та приватної професійної охоронної діяльності, що передбачені п. 8 ч. 2 ст. 115 , ч. 2 ст. 121 , ч. 2 ст. 122 , 194, ч. 2 і 3 ст. 206, ч. 2 і 3 ст. 342, 348, 350 , 352, ч. 2 і 3 ст. 355, ст. ст. 118, 260, 263, 359, 364, 364-1, 365, ч. 2 ст. 366, ч. 2 ст. 367, 368, 368-2, 368-3 КК України.

Окрім спеціальної конфіскації, як іншого заходу кримінально-правового характеру, до порушників кримінально-правових заборон у сфері громадської та приватної професійної охоронної діяльності в Україні, в передбачених законом випадках, можуть бути застосовані такі інші заходи кримінально-правового впливу як заходи кримінально-правового характеру щодо юридичних осіб. Ці засоби державного реагування мають субсидіарний характер, вони застосовуються у додаток до покарання уповноваженої фізичної особи у випадку вчинення нею кримінального правопорушення в інтересах та/або від імені юридичної особи, через фактичну причетність цієї юридичної особи до вчиненого іiі уповноваженою особою злочину або кримінального проступку.

У науковій літературі вже доволі тривалий час точаться дискусії 3 приводу юридичної природи заходів кримінально-правового характеру щодо юридичних осіб (штрафу, ліквідації і конфіскації майна). Так, є група науковців, які послідовно відстоюють позицію, згідно з якою такі заходи кримінально-правового характеру $\epsilon$ нічим іншим, як кримінальною відповідальністю юридичних осіб [6, с.215]. На думку інших, заходи кримінально-правового характеру щодо юридичних осіб не 6 їх кримінальною відповідальністю, оскільки такій відповідальності може підлягати лише фізична особа - суб'єкт кримінального правопорушення. У зв'язку з цим, примусові заходи кримінально-правового 
характеру щодо юридичних осіб (штраф, ліквідації і конфіскації майна) істотно відрізняються від покарання як основного елемента кримінальної відповідальності, хоча і реалізуються в межах такої відповідальності, оскільки знаходять своє зовнішне вираження в обвинувальному вироку щодо її уповноваженої фізичної особи [7, с. 168]. Окремі вітчизняні дослідники, критикуючи останню точку зору, стверджують, що, незважаючи на неможливість юридичної особи бути суб'єктом злочину (через об'єктивну неспроможність вчинити його), кримінальна відповідальність юридичних осіб серед законодавчих інструментів протидії злочинності є цілком допустимою. I можливо це шляхом подальшого вдосконалення інституту кримінальної відповідальності, насамперед, їі форм [8, с. 141].

у спеціальній літературі справедливо підкреслюється теза про те, що з появою в КК України розділу XIV-1 «Заходи кримінально-правового характеру щодо юридичних осіб» юридичні особи офіційно визнані в Україні повноцінними учасниками (суб'єктами) кримінально-правових відносин, а не лише потерпілими особами, як це було до цього. 3 огляду на це, кримінальної відповідальності юридичних осіб в Україні не існує, вона є іншим засобом кримінально-правового характеру відносно кримінальної відповідальності, введення якого посилює превентивну дію закону в справі запобігання вчиненню кримінальних правопорушень в інтересах юридичних осіб [9, с.151].

Запровадження інституту заходів кримінально-правового характеру щодо юридичних осіб $є$ наслідком виконання Україною відповідних міжнародно-правових зобов'язань. Попри це, міжнародні договори не вимагають, щоб відповідальність юридичних осіб за відповідні кримінальні правопорушення була кримінальною. У зв'язку з цим, регламентація у розділі XIV-1 Загальної частини КК України заходів кримінально-правового характеру щодо юридичних осіб свідчить лише про те, що за своїм юридичним змістом ці заходи ні в якому разі не можуть вважатись проявом (формою) кримінальної відповідальності, щонайменше, 3 двох причин: 1) законодавець не визнавав i не визнає юридичних осіб суб'єктом злочину; 2) традиційне розуміння кримінальної відповідальності передбачає, що обов'язковим їі елементом є так званий «державний осуд», який виявляється у визнанні особи винною у вчиненні злочину в резолютивній частині вироку суду, з положень же КК і КПК випливає, що юридична особа не зазнає державного осуду в разі застосування до неї заходів. Це яскраво репрезентовано у ч. 4 ст. 374 КПК України, в якій йдеться не про її осуд, а лише про рішення щодо застосування до юридичної особи заходів кримінально-правового характеру. Отже, заходи кримінально-правового характеру щодо юридичних осіб є окремим видом юридичної відповідальності в кримінальному праві («квазікримінальною відповідальністю») 3 огляду на те, що: 1) фактичною підставою їх застосування є виключно злочин (пункти 1, 3,4 ч. 1 ст. 96-3) або ж фактична ситуація, однією зі складових якої є злочин (п. 2 ч. 1 ст. 96-3); 2) вони $\epsilon$ «реакцією» держави саме на злочин чи зазначену фактичну ситуацію, а не на інші фактичні обставини; 3) ця «реакція» передбачає несприятливі (негативні) наслідки для певного суб'єкта права [10, с.296].

До юридичної особи може бути застосована ліквідація і конфіскація майна - у разі вчинення її уповноваженою особою кримінального правопорушення у вигляді злочину, передбаченого ст. 260 КК України, а також штраф - а) у випадку вчинення iї уповноваженою особою кримінального правопорушення у вигляді злочину, передбаченого ч. 1 i2 ст. 368-3КК України; б) у разі незабезпечення виконання покладених на їі уповноважену особу законом або установчими документами юридичної особи обов'язків щодо вжиття заходів із запобігання корупції, що призвело до вчинення кримінального правопорушення у вигляді злочину, передбаченого ч. 1 і 2ст. 368-3 КК України.

Аіквідація є найбільш суворим заходом кримінально-правового характеру, що може застосовуватись до юридичної особи. 


\section{Кримінальне право, кримінальний процес та криміналістика}

Він передбачає припинення існування юридичної особи як суб'єкта права. Іноді цей захід кримінально-правового характеру ще називають «смертною карою» щодо юридичної особи і застосовується він виключно у випадках, вчинення уповноваженою особою одного із злочинів, прямо перерахованих у ст. 96-9 [10].

К. П. Задоя підкреслює, що ліквідація не може бути застосована у тих випадках, коли регулятивним законодавством не передбачена можливість припинення діяльності певної категорії юридичних осіб на підставі рішення суду. Перш за все мова йде про органи державної влади та місцевого самоврядування - ВР, КМ, суди, сільські, селищні, міські, районні, обласні ради тощо. 3 огляду на це, щодо таких юридичних осіб може бути застосований виключно штраф [10, с. 303-304]. Подібне твердження щодо аспекту регулювання законодавством припинення діяльності певної категорії юридичних осіб на підставі рішення суду можливо, і не позбавлено логіки. Воно, до речі, може становити ще одну обставину серед низки інших, що виключають можливість застосування до юридичних осіб заходів кримінально-правового характеру, яскраво репрезентованих окремими вітчизняними науковцями [11]. До цього варто додати і те, що у такому разі, до таких юридичних осіб ставиться під питання можливість застосування не лише такого заходу кримінально-правового характеру, як ліквідація, але і такого заходу, як конфіскація майна.

Говорячи про конфіскацію майна, ще раз наголосимо, що цей додатковий захід кримінально-правового характеру щодо юридичних осіб застосовується до юридичних осіб одночасно із застосуванням такого обов'язкового заходу, як ліквідація юридичної особи. За справедливим зауваженням О. В. Ермака і В. М. Куца, конфіскація майна юридичної особи - це інший засіб кримінально-правового реагування щодо юридичної особи, що має примусовий, майновий, безоплатний характер та полягає у вилученні у власність держави всього майна юридичної особи і застосовується на підставі вироку суду у разі вчи- нення їі уповноваженою особою одного зі злочинів, передбачених статтями 109, 110 , $113,146,147,160,260,262,258-258-5,437$, 438, 442, 444, 447 КК України лише у випадку застосування до юридичної особи такого основного засобу кримінально-правового реагування як ліквідація. У разі застосування судом конфіскації майна щодо юридичної особи, на відміну від покарання у вигляді конфіскації майна, наступають кримінально-правові наслідки, що полягають у позбавленні їі права власності на майно[9, с. 156].

Згідно з ч. 1 ст. 96-7 КК України штраф є грошовою сумою, що сплачується юридичною особою на підставі судового рішення. Суд застосовує штраф, виходячи 3 двократного розміру незаконно одержаної неправомірної вигоди. У такому разі суд не має правових підстав застосувати штраф у більшому або меншому розмірі [10, с. 303]. Між тим, з огляду на приписи ч. 2 цієї статті у разі, коли неправомірну вигоду не було одержано, або їі розмір неможливо обчислити, суд, у разі вчинення уповноваженою особою юридичної особи злочину, передбаченого ч. 1 ст. 368-3 КК України, застосовує штраф у межах від п'яти до десяти тисяч неоподатковуваних мінімумів доходів громадян, а у випадку вчинення уповноваженою особою юридичної особи злочину, передбаченого ч. 2 ст. 368-3 КК України - від десяти до двадцяти тисяч неоподатковуваних мінімумів доходів громадян;

Під час застосування штрафу за вчинення уповноваженою особою юридичної особи злочину, передбаченого ч. 1 i 2ст. 368-3 КК України, у вищезазначених межах суд має керуватися приписами ст. 96-10 КК України. Цією статтею декларовані загальні засади застосування до юридичної особи такого заходу кримінальноправового характеру, як штраф.

Зі змісту цієї статті вбачається, що при застосуванні до юридичної особи цього заходу кримінально-правового характеру суд має враховувати ступінь тяжкості вчиненого її уповноваженою особою злочину, ступінь здійснення злочинного наміру, розмір завданої шкоди, характер та розмір 
неправомірної вигоди, яка отримана або могла бути отримана юридичною особою, вжиті юридичною особою заходи для запобігання злочину.

Варто мати також на увазі, що штраф як захід кримінально-правового характеру, у випадку вчинення злочину, передбаченого ч. 1 і 2 ст. 368-3 КК України, не може ні якому разі бути застосований судом до державних органів, органів влади Автономної Республіки Крим, органів місцевого самоврядування, організацій, створених ними у встановленому порядку, що повністю утримуються за рахунок відповідно державного чи місцевого бюджетів, фондів загальнообов'язкового державного соціального страхування, Фонду гарантування вкладів фізичних осіб, а також міжнародних організацій.

\section{Висновки та перспективи подальших досліджень}

Наприкінці аналізу проблематики реалізації інших заходів кримінально-правового характеру до порушників кримінально-правових заборон у сфері громадської та приватної професійної охоронної діяльності в Україні хотілося $б$ зазначити, що ми схильні підтримати тих вітчизняних науковців, які пропонують вдосконалити механізм реалізації кримінально-правового впливу щодо юридичних осіб шляхом доповнення переліку підстав застосування до них заходів кримінально-правового характеру (ст. 96-3 КК України) випадками вчинення кримінальних правопорушень, у вигляді злочинів, передбачених іншими статтями Особливої частини КК України (ст. 222-1, 223-1, 223-2, 232-1, 232-2, 255, 257 КК України та ін.).

3 огляду на предмет нашого дослідження вважаємо, що перелік підстав застосування до юридичних осіб заходів кримінально-правового характеру (ст. 96-3 КК України) доцільно також доповнити за рахунок включення до нього кримінальних правопорушень у сфері громадської та приватної професійної охоронної діяльності, передбачених ст. 194, 206, 352, 355 , 359, 368, 368-2 КК України.

\section{Мітература}

1. Хавронюк М. І. Заходи кримінальноправового впливу: які вони бувають? Юридичний вісник України . № 21 (934). 2013. C. 6-7.

2. Кримінальне право України: Загальначастина: підручник В. І. Борисов, В. Я. Тацій, В. І. Тютюгін та ін.; за ред. В. Я. Тація, В. І. Борисова, В. I. Тютюгіна; 5-те вид., переробл. ідопов. Харків: Право, 2015. 468 с.

3. Аналіз стану здійснення судочинства судами кримінальної юрисдикції у 2017 році / Відділ аналізу судової статистики судів кримінальної юрисдикції правового управління (III) департаменту аналітичної та правової роботи Верховного Суду 16 березня 2018 р. / Верховний суд. URL: https://supreme.court.gov.ua/userfiles/ Analiz_krum_sud_2017.pdf (дата звернення 23.09.2019).

4. Корабель М. Г., Шинкарьов Ю. В. Конфіскація майна як вид кримінального покарання: монографія. Харків: Права, 2018. 176 с.

5. Огляд судової практики Касаційного кримінального суду у складі Верховного суду: щодо призначення покарання / Аналітичні огляди / Верховний суд. URL: https://supreme.court.gov.ua/userfiles/ media/ogljad_kks_vs.pdf (дата звернення 23.10.2019).

6. Грищук В. К., Пасєка О. Ф. Кримінальна відповідальність юридичних осіб: порівняльно-правове дослідження: монографія. Аьвів: Аьвів. держ. ун-т внутр. справ, 2013. 248 с.

7. Аитвинов О. М., Ященко А. М. Заходи кримінально-правового характеру щодо юридичних осіб: деякі міркування щодо форм реалізації та юридичної природи / Фундаментальні проблеми кримінальної відповідальності: матер. наук. полілогу, м. Харків, 7 верес. 2018. / Упоряд.: Ю. В. Баулін, Ю. А. Пономаренко. Харків: Право, 2018. 208 с.

8. Куц В. М., Сотниченко В. С. Юридична особа як об'єкт застосування кримінально-правових заходів: монографія. Київ: Нац. акад.. прокурат. України, 2017. 250 c. 


\section{Кримінальне право, кримінальний процес та криміналістика}

9. Єрмак О. В., Куц В. М. Конфіскація як засіб кримінально-правового реагування: монографія. Чернігів: Видавець Аозовий В.М., 2018. 232 с.

10. Науково-практичний коментар Кримінального кодексу України / за ред. М. І. Мельника, М. І. Хавронюка.10-те вид., переробл. та допов. Київ: ВД «Дакор», 2018. 1368 с.

11. Ященко А. М. Обставини, що виключають можливість застосування до юридичних осіб заходів кримінально-правового характеру. Підприємниитво, господарство і право. 2016. № 12. С. 227-232.

\section{SUMMARY}

It has been established that the preconditions for the emergence of the institution of other measures of criminal and legal nature (Section XIV) and measures of criminal and legal nature for legal entities (Section XIV-1) are political and legal reforms related to approaching Ukrainian legislation to European standards.

It has been determined that scientific and practical approaches to the main features of other measures of criminal and legal nature are ambiguous, and sometimes contradictory; it has been also defined that there are significant differences in the conceptual apparatus, and that is why an extensive scientific search in the directions of clarifying problematic issues with the purpose of successful introduction of innovations into lawenforcement activity is urgent.

The author has studied the basic doctrinal approaches to formulating the concept and defining the types of other measures of criminal and legal nature. The author has determined those crimes in the sphere of security activities, for the commission of which other measures of criminal and legal nature may be applied.

Special attention has been paid to the necessity of improving the mechanism of implementation of measures of criminal and legal nature in relation to legal entities by supplementing the list of grounds for their application.

The author has analyzed some other measures of criminal and legal nature for criminal offenses that encroach on public and private professional security activities in the context of their legal nature and the introduction in regard to legal entities.

It has been concluded that it is expedient to supplement the list of grounds for applying measures of criminal and legal nature to the legal entities by including criminal offenses in the sphere of public and private professional security activities provided for in the Articles 194, 206, 352, 355, 359, 368, 368-2 of the Criminal Code of Ukraine.

Key words: measures of criminal nature, punishment, security activities, private security activities, criminal liability, crimes in the field of security activities. 